\title{
UJI PRAKLINIK ANTIHIPERURISEMIA SECARA IN VIVO PADA MENCIT PUTIH JANTAN GALUR BALB-C DARI EKSTRAK DAUN SALAM (Syzigium polyanthum Walp) DAN DAUN BELIMBING WULUH (Averrhoa bilimbi L.)
}

\author{
Muhtadi $^{1^{*)}}$, Andi Suhendi' ${ }^{1)}$, Nurcahyanti W.2), dan EM. Sutrisna ${ }^{3)}$ \\ ${ }^{1}$ Bagian Kimia Farmasi, Fakultas Farmasi, Universitas Muhammadiyah Surakarta \\ ${ }^{2}$ Bagian Biologi Farmasi, Fakultas Farmasi, Universitas Muhammadiyah Surakarta \\ ${ }^{3}$ Bagian Farmakologi Fakultas Kedokteran \& Farmasi Universitas Muhammadiyah Surakarta
}

\begin{abstract}
Antihyperuricemia activity in vivo testing has been done of single and combined extracts of Salam (Syzigium polyanthum Walp) and Belimbing Wuluh leaves (Averrhoa bilimbi L.), and also standardized extracts. Salam leaves extraction and Belimbing Wuluh leaves carried by the water solvent. Dried extract of each ingredient had been done antihyperuricemia preclinical in vivo testing against male white mice strain Balb- $C$ induced by potassium oxonate dose of $250 \mathrm{mg} / \mathrm{kg}$ b. $w$. Antihyperuricemia preclinical in vivo testing results showed that the single extracts of Salam and Belimbing Wuluh at a dose of $200 \mathrm{mg} / \mathrm{kg} \mathrm{b.w.} \mathrm{had} \mathrm{lower} \mathrm{activity} \mathrm{levels} \mathrm{of} \mathrm{uric} \mathrm{acid}$ in the blood serum of male white mice, respectively 0.640 and 0.680 . While the activity of the combination of extracts of Salam-Belimbing Wuluh is 1.380 .
\end{abstract}

Keywords: Antihyperurisemia preclinical in vivo testing; Salam leaves extract, Belimbing Wuluh leaves extract, male white mice Balb- $C$

\section{PENDAHULUAN}

Asam urat adalah senyawa turunan purina dengan rumus kimia $\mathrm{C}_{5} \mathrm{H}_{4} \mathrm{~N}_{4} \mathrm{O}_{3}$ dan rasio plasma antara $3,6 \mathrm{mg} / \mathrm{dL}(\sim 214 \mu \mathrm{mol} / \mathrm{L})$ dan $8,3 \mathrm{mg} /$ $\mathrm{dL}(\sim 494 \mu \mathrm{mol} / \mathrm{L})(1 \mathrm{mg} / \mathrm{dL}=59,48 \mu \mathrm{mol} / \mathrm{L})$. Kelebihan (hiperurisemia, hyperuricemia) atau kekurangan (hipourisemia, hyporuricemia) kadar asam urat dalam plasma darah ini sering menjadi indikasi adanya penyakit atau gangguan pada tubuh manusia. Pada manusia, asam urat adalah produk terakhir lintasan katabolisme nukleotida purina, sebab tiadanya enzim urikase yang mengkonversi asam urat menjadi alantoin. Kadar asam urat yang berlebih dapat menimbulkan batu ginjal dan/atau pirai di persendian (Hediger, 2004).

Penyakit asam urat merupakan akibat dari konsumsi zat purin secara berlebihan. Purin diolah tubuh menjadi asam urat, tapi jika kadar asam urat berlebih, ginjal tidak mampu mengeluarkan sehingga kristal asam urat menumpuk di persendian. Akibatnya sendi terasa nyeri, bengkak dan meradang. Asam urat adalah penyakit dari sisa metabolisme zat purin yang berasal dari sisa makanan yang kita konsumsi. Purin sendiri adalah zat yang terdapat dalam setiap bahan makanan yang berasal dari tubuh makhluk hidup. Dengan kata lain, dalam tubuh makhluk hidup terdapat zat purin ini, lalu karena kita memakan makhluk hidup tersebut, maka zat purin tersebut berpindah ke dalam tubuh kita. Berbagai sayuran dan buahbuahan juga terdapat purin. Purin juga dihasilkan dari hasil perusakan sel-sel tubuh yang terjadi secara normal atau karena penyakit tertentu. Biasanya asam urat menyerang pada usia lanjut, karena penumpukan bahan purin ini.Pemanfaatan obat tradisional atau jamu di Indonesia pada hakekatnya merupakan bagian kebudayaan bangsa Indonesia. Keuntungan dari penggunaan obat (ramuan) tradisional pada prinsipnya adalah efek samping yang relatif kecil dibandingkan obat modern. Meskipun secara empiris obat tradisional mampu menyembuhkan berbagai macam penyakit, tetapi khasiat dan kemampuannya belum banyak dibuktikan secara ilmiah maupun klinis. Selain 
itu, belum banyak diketahui senyawa kimia apa yang bertanggung jawab terhadap khasiat obat tradisional tersebut (Wijayakusuma, 2002).

Hasil penelitian sebelumnya, menunjukkan bahwa dekokta daun salam pada dosis $1,25 \mathrm{~g} /$ $\mathrm{kg}$ BB mampu menurunkan kadar asam urat dalam darah mencit putih jantan secara efektif (Handadari, 2007). Sedangkan infusa daun Salam pada dosis $2,5 \mathrm{~g} / \mathrm{kg}$ BB mampu menurunkan kadar asam urat yang setara dengan allopurinol dosis 10 $\mathrm{mg} / \mathrm{kg}$ BB (Ariyanti, 2007). Belimbing wuluh dilaporkan oleh Muhtadi dkk. memiliki aktivitas antihiperurisemia yang cukup kuat dibandingkan dengan meniran, tempuyung dan jinten hitam dengan nilai penurunan sebesar 78,06\% (Muhtadi dkk., 2010).

Tulisan ini menjelaskan tentang pengujian aktivitas antihiperurisemia secara in vivo pada mencit putih jantan galur Balb-C dari ekstrak air daun Salam, dan Belimbing Wuluh, baik dosis tunggal maupun dosis kombinasi.

\section{Metode}

Alat yang digunakan dalam penelitian ini adalah spuit injeksi volume $3,0 \mathrm{ml}$ (Terumo), spuit injeksi untuk insulin 1,0 ml, spuit oral ukuran 15 gauge, flakon, timbangan mencit kapasitas 2610 gram (Lark, Cina), timbangan analitik (Presica A-SCS), pipa kapiler (Assistent), mikrotube sentrifuge (eppendorf), sentrifuge (mini spin), vortex, mikropipet ukuran 5-40 $\mu 1$ dan 200-1000 $\mu 1$, blue tip, yellow tip, alat-alat gelas (Pyrex), StarDust FC* 15 (DyaSys) dan kuvet disposibel. Bahan penelitain adalah Ekstrak air daun Salam dan daun Belimbing Wuluh, Potasium oksonat p.a (Aldrich Chemical Company), Allopurinol p.a (Sigma), $\mathrm{NaCl}$ 0,9\%, Aquadest dan reagen kit uric acid FS*TBHBA (DyaSys).

Hewan percobaan: mencit putih jantan galur Balb-C dengan berat badan rata-rata $30-40$ gram dan berumur 2-3 bulan.

Ekstraksi dilakukan dengan cara serbuk daun salam atau daun Belimbing Wuluh direbus dengan air sampai volume menjadi separoh dari volume awal, kemudian disaring dan filtrat dievaporasi dengan rotary evaporator (RE) sehingga diperoleh ekstrak kental. Kemudian ekstrak kental yang diproleh dikeringkan dalam Vaccum Dryer dan Vaccum Oven sampai kering.

Pembuatan Hiperurisemia dilakukan dengan cara menginjeksikan secara intraperitonial potasium oksonat $250 \mathrm{mg} / \mathrm{kg} \mathrm{BB}$ atau $5 \mathrm{mg} / 20 \mathrm{~g}$ BB pada mencit (Zhao et al., 2005).

Uji pendahulun ini dilakukan untuk tujuan mendapatkan data tentang dosis ekstrak, waktu pengambilan darah, dan ekstrak tunggal yang aktif dalam menurunkan kadar asam urat.

Hewan uji dibagi menjadi beberapa kelompok perlakuan, yaitu meliputi: kelompok kontrol negatif / hiperurisemia (potassium oksonat dosis $250 \mathrm{mg} / \mathrm{kgBB}$ ), kontrol positif (allopurinol dosis $10 \mathrm{mg} / \mathrm{kgBB}$ ), ekstrak air daun salam dan Belimbing Wuluh dosis tunggal (200 mg/kgBB). Pemberian sediaan uji dilakukan satu jam setelah induksi hiperurisemia (potassium oksonat dosis $250 \mathrm{mg} / \mathrm{kgBB}$ ). Pengambilan darah dilakukan satu jam setelah pemberian sediaan uji atau dua jam setelah induksi hiperurisemia (potassium oksonat dosis $250 \mathrm{mg} / \mathrm{kgBB}$ ), darah diambil lewat mata mencit dengan cara menusuk cabang vena opthalmicus yang terletak pada saccus medianus orbitales dengan pipa kapiler. Darah yang mengalir lewat pipa kapiler ditampung dalam tabung ependorf, setelah darah menggumpal disentrifus untuk mendapatkan serum.

Kadar asam urat ditetapkan berdasarkan reaksi enzimatik menggunakan reagen uric acid FS* TBHBA. Serum darah yang telah dicampur homogen dengan pereaksi uric acid $\mathrm{FS}^{*}$ TBHBA diinkubasi selama 10 menit pada suhu $37^{\circ} \mathrm{C}$. Selanjutnya larutan sampel, standart dan blangko dibaca absorbansinya dengan menggunakan spektrofotometer StartDust FC*15 pada panjang gelombang $546 \mathrm{~nm}$.

\section{HASIL DAN PEMBAHASAN}

Uji pendahuluan dilakukan untuk mengetahui bagaimana model hiperurisemia pada mencit putih jantan, yaitu dengan mencari dosis efektif potasium oksonat dalam menaikkan kadar asam urat dari kondisi normal. 
Tabel 1- Data uji pendahuluan pembuatan model hiperurisemia

\begin{tabular}{ccccc}
\hline Perlakuan & No. HU & Kadar Asam Urat (mg/dL) & Rata-rata & SD \\
\hline Kontrol normal & 1 & 1.3 & & \\
(Tanpa Perlakuan) & 2 & 1.7 & 1.433 & 0.231 \\
& 3 & 1.3 & & \\
\hline Potasium oksonat & 1 & 3.1 & 3.067 & 0.950 \\
Dosis 250 mg/kgBB & 2 & 4 & & \\
\hline
\end{tabular}

Dari hasil uji pendahuluan tersebut dapat dilihat bahwa dengan potassium dosis $250 \mathrm{mg} /$ kgBB telah mampu menikkan kadar asam urat mencit yaitu dari kadar normal dengan ratarata $1,433 \mathrm{mg} / \mathrm{dL}$ menjadi $3,067 \mathrm{mg} / \mathrm{kgBB}$. Hal ini sesuai dengan pernyataan yang mengatakan bahwa mencit dikatakan hiperurisemia jika kadar asam urat darahnya berkisar antara 1,7-3,0 mg/dL. Dan setelah diuji statistik diperoleh hasil bahwa antara kontrol normal dan kelompok potassium oksonat sangat berbeda signifikan yaitu dengan nilai signifikansi sebesar $0,205(p>0,05)$. Jadi, dari hasil tersebut metode dalam penelitian dapat dilanjutkan penelitian selanjutnya yaitu perlakuan dengan ekstrak.

Hewan uji yang digunakan pada penelitian ini adalah mencit putih jantan (Mus muculus) yang memiliki enzim urikase yang dapat memecah asam urat dengan membentuk produk akhir allantoin yang bersifat mudah larut dalam air (Martin, 1987). Untuk memperkecil variasi biologis, maka peneliti melakukan pengendalian terhadap beberapa variabel antara lain dengan cara menggunakan hewan uji yang kurang lebih sama variasi biologisnya yaitu diantaranya dengan berat badan sekitar 30 - 40 gram, umur 2-3 bulan, galur Balb-C, jenis kelamin jantan dan diperlakukan sama yaitu ditempatkan dalam kandang dengan jumlah tiap kandangnya sama dan diberi makanan yang sama serta sebelum diberi perlakuan hewan uji dipuasakan terlebih dahulu selama \pm 2 jam dengan tetap diberi minum ad libitum. Hal ini dilakukan agar kondisi hewan uji sama dan untuk mengurangi pengaruh makanan yang dikonsumsi terhadap sediaan iji yang diberikan dalam penelitian. Dan untuk mengurangi tingkat kestresan hewan uji diadaptasikan dengan kondisi laboratorium selama 7 hari.

Pemilihan jenis kelamin jantan lebih didasarkan pada pertimbangan bahwa mencit jantan tidak mempunyai hormone estrogen, jikalaupun ada hanya dalam jumlah yang relative sedikit serta kondisi hormonal pada jantan lebih stabil jika dibandingkan dengan mencit betina karena pada mencit betina mengalami perubahan hormonal pada masa-masa tertentu seperti pada masa siklus estrus, masa kehamilan dan menyusui dimana kondisi tersebut dapat mempengaruhi kondisi psikologis hewan uji tersebut. Selain itu tingkat stress pada mencit betina lebih tinggi dibandingkan dengan mencit jantan yang mungkin dapat mengganggu pada saat pengujian.

Potasium oksonat digunakan sebagai induktor hiperurisemia karena potasium oksonat merupakan inhibitor urikase yang kompetitif ntuk meningkatkan kadar asam urat dengan jalan mencegah perubahan asam urat menjadi allantoin. Dimana allantoin bersifat larut air dan dapat diekskresi lewat urin, sehingga dengan dihambatnya enzim rikase oleh potassium oksonat maka asam urat akan tertumpuk dan tidak tereliminasi dalam bentuk urin.

Kontrol positif yang digunakan adalah allopurinol yaitu salah satu obat pirai atau goutyang sering digunakan dalam pengobatan. Allopurinol merupakan satu-satunya urikostatikum yang saat ini digunakan secara terapeutik, dimana bekerja untuk mengurangi pembentukan asam urat. Sedangkan yang bekerja untuk meningkatkan eliminasi asam urat disebut urikosurika (Mutschler, 1991). Allopurinol merupakan substrat ksantin oksidase dan dieliminasi melalui ginjal terutama sebagai oksipurinol (sering juga disebut dengan istilah yang salah yaitu aloksantin) (Schunack dan Mayer, 1990). Allopurinol maupun oksipurinol, menghambat ksantin dan asam urat, dimana dalam dosis rendah mekanisme penghambatan berlangsung secara kompetitif dan dalam dosis tinggi bekerja secara tidak kompetitif. Allopurinol yang memiliki waktu paroh dalam 
plasma sekitar 40 menit, dihidrolisis oleh ksantin oksidase menjadi metabolit (Mutschler, 1991). Metabolit allopurinol-1-ribonukleotida, yang dapat dinyatakan kecil dalam ekstrak organ, mungkin bertanggung jawab untuk inhibisi tambahan dari sintesis de novo purin (Schunack dan Mayer, 1990). Melalui penghambatan ksantin oksidase maka hipoksantin dan ksantin diekskresi lebih banyak dalam urin sehingga kadar asam urat dalam darah dan urin menurun (Mutschler, 1991).

Sediaan uji yang digunakan untuk menurunkan kadar asam urat dalam penelitian ini adalah ekstrak air dari daun belimbing wuluh. Metode penyarian yang digunakan adalah ekstraksi dengan pelarut air, dimana metode tersebut mirip dengan penggunaan bahan nabati sebagai obat tradisional (jamu) yaitu dengan merebus bahan dan mengambil konsentratnya untuk diminum sehingga kesetaraan perlakuan secara tradisional dan perlakuan dalam penelitian identik. Bedanya dalam penelitian ini konsentrat yang diperoleh setelah perebusan diuapkan dalam vacuum dryer sampai tebentuk ekstrak kering. Hal ini dimaksudkan untuk menjaga stabilitasnya selama penyimpanan karena jika disimpan dalam bentuk cair sangat rentan terkontaminasi serta cepat ditumbuhi oleh jamur.

Penetapan kadar asam urat ditetapkan dengan metode enzimatik dengan menggunakan reagen Uric acid FS*TBHBA (2,4,6-tribromo3 hydroxybenzoic acid) dengan menggunakan alat spektrofotometer StarDust FC 15. Mekanisme yang terjadi adalah asam urat dioksidasi oleh enzim urikase dengan bantuan $\mathrm{H}_{2} \mathrm{O}$ dan $\mathrm{O}_{2}$ menjadi allantoin, karbondioksida dan hidrogen peroksida. Hidrogen peroksida yang terbentuk akan bereaksi dengan 4-aminoantipirin dan TBHBA menjadi kuinonimin yang berwarna merah muda dimana reaksi tersebut dikatalisis oleh enzim peroksidase (POD). Besarnya intensitas warna yang dihasilkan oleh kuinonimin tersebut ekuivalen dengan kadar asam urat dalam darah. Mekanisme reaksi tersebut dapat dilihat pada gambar 1 .

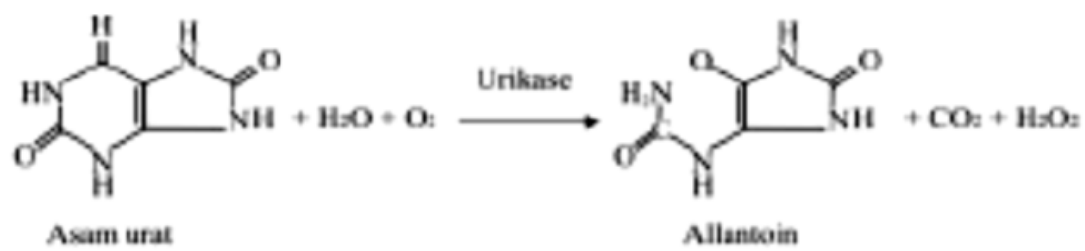<smiles>CC1C(N)C(O)N(C2=CC=CCC2)C1C</smiles>
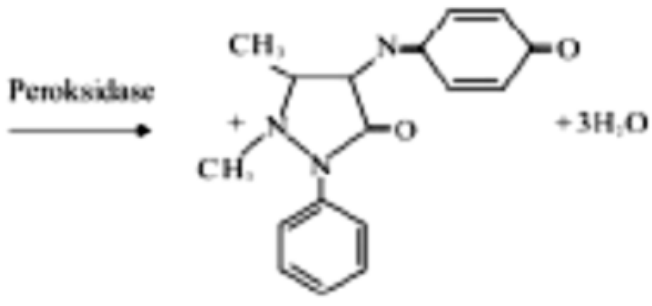

Kuinonimin

Gambar 1- Mekanisme Reaksi Pembentukan Senyawa Kuinonimin (Schunack et al., 1990)

Dalam penetapan kadar perlu diperhatikan kemungkinan adanya senyawa pengganggu yaitu terutama dari sel-sel darah merah. senyawa dalam sel darah merah yang diketahui paling mengganggu adalah glutation dan ergotion. Untuk mengurangi ganguan tersebut digunakan darah yang tidak hemolisis, sehingga dalam penelitian ini yang digunakan adalah serum bukan plasma untuk mencegah agar glutation dan ergation tidak lepas dari sel darah merah (Dawiesh, 1989). 


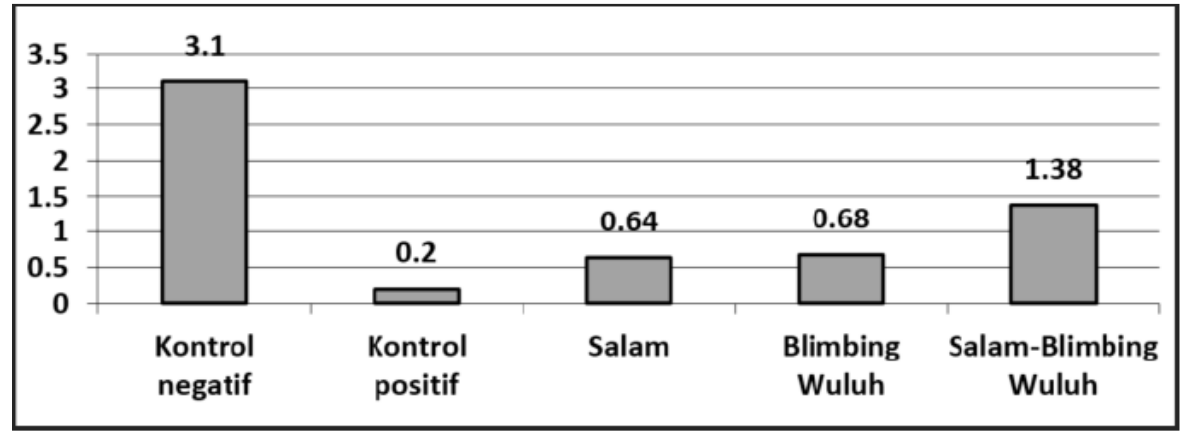

Gambar 2- Histogram hubungan antara kelompok perlakuan dengan rata-rata kadar asam urat darah $(\mathrm{mg} / \mathrm{dL})$ pada mencit putih jantan

Data kadar asam urat dalam serum mencit pemberian sediaan uji ekstrak dosis tunggal 200 setelah diinduksi dengan potasium oksonat dan $\mathrm{mg} / \mathrm{kgBB}$ tersaji pada tabel berikut:

Tabel 2- Data Kadar Asam Urat Dalam Serum Setelah Perlakuan dengan Ekstrak

\begin{tabular}{|c|c|c|c|c|c|}
\hline \multirow[b]{2}{*}{ No. HU } & \multirow[b]{2}{*}{ KELOMPOK PERLAKUAN } & \multirow[b]{2}{*}{ BB (Gram) } & \multicolumn{3}{|c|}{ KADAR ASAM URAT } \\
\hline & & & SETELAH PERLAKUAN & $\begin{array}{l}\text { RATA- } \\
\text { RATA }\end{array}$ & SD \\
\hline 1 & \multirow{5}{*}{$\begin{array}{c}\text { Kontrol Negatif } \\
\text { (Potasium Oksonat } 250 \text { mg/kgBB) }\end{array}$} & 39.3 & 3.1 & \multirow{5}{*}{3.100} & \multirow{5}{*}{0.3464} \\
\hline 2 & & 30.5 & 3.7 & & \\
\hline 3 & & 30 & 2.9 & & \\
\hline 4 & & 36 & 2.9 & & \\
\hline 5 & & 39 & 2.9 & & \\
\hline 1 & \multirow{5}{*}{$\begin{array}{c}\text { Kontrol Positif } \\
\text { (Allopurinol } 10 \mathrm{mg} / \mathrm{kgBB} \text { ) }\end{array}$} & 37.5 & 0.1 & \multirow{5}{*}{0.2000} & \multirow{5}{*}{0.1000} \\
\hline 2 & & 36.5 & 0.2 & & \\
\hline 3 & & 36 & 0.3 & & \\
\hline 4 & & 39 & 0.3 & & \\
\hline 5 & & 38.5 & 0.1 & & \\
\hline 1 & \multirow{5}{*}{$\begin{array}{l}\text { Ekstrak Daun Salam } \\
\quad(200 \mathrm{mg} / \mathrm{kgBB})\end{array}$} & 36 & 0.5 & \multirow{5}{*}{0.6400} & \multirow{5}{*}{0.1673} \\
\hline 2 & & 36.5 & 0.5 & & \\
\hline 3 & & 37.5 & 0.9 & & \\
\hline 4 & & 38.5 & 0.6 & & \\
\hline 5 & & 39 & 0.7 & & \\
\hline 1 & \multirow{5}{*}{$\begin{array}{l}\text { Ekstrak Belimbing Wuluh } \\
\quad(200 \mathrm{mg} / \mathrm{kgBB})\end{array}$} & 35 & 1 & \multirow{5}{*}{0.6800} & \multirow{5}{*}{0.3493} \\
\hline 2 & & 34 & 0.3 & & \\
\hline 3 & & 32.5 & 0.3 & & \\
\hline 4 & & 36 & 0.9 & & \\
\hline 5 & & 35 & 0.9 & & \\
\hline 1 & \multirow{5}{*}{$\begin{array}{c}\text { Ekstrak Salam - Belimbing Wuluh } \\
(200 \mathrm{mg} / \mathrm{kgBB}) \\
1: 1\end{array}$} & 36.5 & 1.3 & \multirow{5}{*}{1.3800} & \multirow{5}{*}{0.4087} \\
\hline 2 & & 37.5 & 1.3 & & \\
\hline 3 & & 36.5 & 1.6 & & \\
\hline 4 & & 38 & 1.9 & & \\
\hline 5 & & 37 & 0.8 & & \\
\hline
\end{tabular}


Dari hasil yang tertera dalam tabel diatas, setelah diuji statistik diperoleh hasil signifikansi masing-masing kelompok perlakuan seperti tertera pada tabel berikut:

Tabel 3- Hasil Uji Anova Setelah Perlakuan Dengan Ekstrak Tunggal

\begin{tabular}{cccccc}
\hline Kelompok & I & II & III & IV & V \\
\hline I & - & $0,000^{*}$ & $0,000^{*}$ & $0,000^{*}$ & $0,000^{*}$ \\
II & - & - & $0,031^{*}$ & $0,020^{*}$ & $0,000^{*}$ \\
III & - & - & - & 0,835 & $0,001^{*}$ \\
IV & - & - & - & - & $0,001^{*}$ \\
V & - & - & - & - & - \\
\hline
\end{tabular}

Ket: * : menunjukkan perbedaan yang signifikan yaitu $\mathrm{P}<0,05$.

Kelompok I : kontrol negatif/hiperurisemia (potassium oksonat $250 \mathrm{mg} / \mathrm{kgBB}$ )

Kelompok II : kontrol positif (allopurinol $10 \mathrm{mg} / \mathrm{kgBB}$ )

Kelompok III : ekstrak air daun Salam $(200 \mathrm{mg} / \mathrm{kgBB})$

Kelompok IV : ekstrak air daun Belimbing Wuluh (200 mg/kgBB)

Kelompok V : ekstrak kombinasi Salam-Belimbing Wuluh $(200 \mathrm{mg} / \mathrm{kgBB})$

Dari hasil uji anova diatas dapat dilihat bahwa kadar asam urat antara kontrol negative dengan kontrol positif maupun dengan kelompok ekstrak menunjukan hasil yang berbeda signifikan dengan nilai signifikansi sebesar 0,000 . Hal ini menunjukkan bahwa allopurinol dan ekstrak daun salam, Belimbing Wuluh maupun kombinasi ekstrak salam dan Belimbing Wuluh mampu menurunkan kadar asam urat dalam darah mencit putih jantan galur Balb-C jika dibandingkan dengan kontrol negatif (Potasium oksonat).

Jika dibandingkan dengan kontrol positif, penurunan yang dihasilkan oleh ekstrak tunggal daun salam dan Belimbing Wuluh berbeda signifikan dengan nilai berturut-turut 0,031 dan $0,020(\mathrm{P}<0,005)$. Dari hasil yang diperoleh dapat dikatakan bahwa kedua ekstrak dengan dosis tunggal memiliki potensiasi yang sama dalam menurunkan kadar asam urat mencit putih jantan galur Balb-C dimana hal tersebut didukung dengan hasil statistik antara kedua ekstrak adalah berbeda tidak signifikan dengan nilai signifikansi sebesar 0,835 $(\mathrm{P}>0,05)$.

Sedangkan kombinasi ekstrak SalamBelimbing Wuluh jika dibandingkan dengan kontrol positif berbeda signifikan dengan nilai $\mathrm{P}=0,000(\mathrm{P}<0,05)$. Hal ini berarti penurunan yang dihasilkan oleh kombinasi ekstrak salam dan Belimbing Wuluh berbeda jauh dengan penurunan yang dihasilkan oleh allopurinol. Dan jika dibandingkan dengan ekstrak tunggal Salam maupun Belimbing wuluh memberikan hasil yang berbeda tidak signifikan. Dari hasil tersebut dapat disimpulkan bahwa pemberian ekstrak kombinasi dari dua ekstrak tunggal yang masing-masing potensial dalam menurunkan asam urat darah mencit jika digabungkan akan memberikan hasil yang lebih baik karena senyawa aktif masingmasing ekstrak berbeda.

\section{SIMPULAN}

Ekstrak daun Salam dan daun Belimbing Wuluh dosis tunggal $200 \mathrm{mg} / \mathrm{kgBB}$ terbukti berpotensi menurunkan kadar asam urat dalam darah mencit putih jantan galur Balb-C yang dinduksi potassium oksonat dimana prosentase penurunan kadar asam urat yang diberikan oleh ekstrak Salam kurang lebih sebesar 79,35\% dan ekstrak Belimbing Wuluh sebesar 78,06\% sedangkan penurunan oleh allopurinol sebesar 93,55\%. Penurunan kadar asam urat dalam serum dari kombinasi eksrak Salam dan Belimbing Wuluh dengan perbandingan sama $(1: 1)$ memberikan hasil yang berbeda tidak signifikan dengan kontrol positif yaitu dengan prosentase penurunan sebesar $55,48 \%$.

\section{DAFTAR PUSTAKA}

Ariyanti, R., 2007, Pengaruh Pemberian Infusa Daun Salam (Eugenia polyantha Wight.)Terhadap Penurunan Kadar Asam Urat dalam Darah Mencit Putih Jantan hiperurisemia, Fakultas Farmasi Universitas Muhammadiyah Surakarta, Surakarta.

Dawiesah, I. S., 1989, Penentuan Nutrien dalam Jaringan dan Plasma Tubuh, Hal 54-61, PAU Pangan dan Gizi, UGM. Yogyakarta.

Departemen Kesehatan Republik Indonesia. 1978. Materia Medika Indonesia. Jilid 4. Jakarta. 109-111.

Handadari, H. R., 2007, Efek Decocta Daun Salam (Eugenia polyantha Wight.) Terhadap Penurunan Kadar Asam Urat dalam 
Darah Mencit Putih (Mus muculus) Jantan hiperurisemia, Fakultas Farmasi Universitas Muhammadiyah Surakarta, Surakarta.

Hediger MA. 2004 . Physiology and biochemistry of uric acid. Review. Ther Umsch. PubMed PMID: 15493112. 61(9):541-5

Martin, D. W., 1987, Metabolisme Nukleotida Purin dan Pirimidin dalam Biokimia Harper, Edisi 20, diterjemahkan oleh Darmawan, Iyan, Penerbit Buku Kedokteran EGC, Jakarta.

Muhtadi, Andi Suhendi, Nurcahyanti W., EM. Sutrisna, 2010, Pengembangan Agen Fitoterapi Asam Urat Dari Beberapa TumBuhan Obat Indonesia Untuk Peningkatan Kapasitas Bahan Alam Obat Menjadi Produk Obat Herbal Terstandar (OHT), Laporan Penelitian RAPID, Universitas Muhammadiyah Surakarta.
Mutschler, E., 1991, Dinamika Obat, Buku Ajar Farmakologi dan Toksikologi, Edisi Kelima, ITB, Bandung, 217-221.

Schunack, W., Mayer, and K., Manfred, H., 1990, Senyawa Obat Kimia Farmasi, diterjemahkan oleh Joke, Witlmena dan Soebita, S., Gajah Mada University Press, Yogyakarta.

Wijayakusuma, H., 2002, Tumbuhan Berkhasiat Obat Indonesia Rempah, Rimpang dan Umbi. Prestasi Instan Indonesia, Jakarta. 